\title{
Development of Interactive Learning Multimedia Indonesia's Cultural Diversity Material in Social Sciences Learning for Grade IV Elementary School Students
}

\author{
Ni Kadek Dwi Puspita Sari \\ Faculty of Education, Ganesha University of Education, Singaraja, Indonesia \\ e-mail: nikadekdwipuspitasari31@undiksha.ac.id \\ I Komang Ngurah Wiyasa \\ Faculty of Education, Ganesha University of Education, Singaraja, Indonesia \\ e-mail:ngrh.wiyasa@undiksha.ac.id
}

\section{A R T I C L E I N F O \\ Article history: \\ 25 December 2020 \\ Received in revised form \\ 01 January 2021 \\ Accepted 25 January 2021 \\ Available online 03 Pebruari \\ 2021 \\ Kata Kunci: \\ IPS, Multimedia Interaktif, \\ Keberagaman Budaya \\ Keywords: \\ IPS, Interactive Multimedia, \\ Cultural Diversity}

\begin{abstract}
A B S T R A K
Pelaksanaan Pembelajaran Jarak Jauh di SD pada masa pandemi Covid-19 melalui pengamatan pra-penelitian ditemukan bahwa lebih banyak menggunakan media pembelajaran yang monoton sehingga menyebabkan siswa bosan dalam melaksanakan pembelajaran jarak jauh. Siswa SD menjadikan IPS sebagai muatan yang paling tidak disenangi serta rendahnya pengetahuan siswa SD terhadap keberagaman budaya bangsa menjadi masalah yang cukup serius dan harus segera ditangani. Penelitian ini bertujuan untuk mengembangkan media pembelajaran berupa Multimedia Pembelajaran Interaktif materi Keberagaman Budaya Indonesia pada Pembelajaran IPS Siswa Kelas IV SD. Penelitian ini merupakan jenis penelitian R\&D dengan model pengembangan ADDIE. Penelitian ini melibatkan 3 validator yakni ahli materi, ahli desain pembelajaran, dan ahli media serta reviewer yakni 1 orang guru serta 12 orang siswa kelas IV SD. Metode pengumpulan data dan analisis data menggunakan angket serta metode analisis deskriptif. Dalam uji coba oleh ahli materi memperoleh hasil persentase skor sebesar $90,0 \%$, oleh ahli desain pembelajaran dengan persentase skor sebesar $92,5 \%$, ahli media memperoleh hasil persentase skor sebesar $95,0 \%$ sehingga dari uji ahli memperoleh kategori A kualifikasi sangat baik dengan keterangan produk sangat layak. Hasil review
\end{abstract} dari 1 orang guru dengan persentase skor sebesar 91,7\%, review 3 orang siswa dalam uji coba perorangan dengan persentase skor sebesar $91,1 \%$, hasil review 12 orang siswa dalam uji coba kelompok kecil dengan persentase skor sebesar 93,9\% termasuk dalam kategori A kualifikasi sangat baik, sehingga berdasarkan hasil yang diperoleh tersebut, maka multimedia pembelajaran interaktif materi keberagaman budaya Indonesia yang dikembangkan merupakan media yang sangat layak untuk digunakan pada pembelajaran IPS siswa kelas IV SD.

\begin{abstract}
A B S T R A C T
Implementation of distance learning in elementary school during the Covid-19 pandemic, through pre-research observations it was found that many use monotonous learning media causing students get bored in practice distance learning. Elementary school students make social sciences as their least preferred content and the low knowledge of elementary school students about the diversity of national cultures becomes a serious problem and must be addressed immediately. This research aims to developed learning media in the form of interactive learning multimedia material on Indonesia cultural diversity in social sciences learning for fourth grade elementary school students. This research is a type of R\&D (Research and Development) using the ADDIE development model. This research was involved 3 validators namely material, instructional design, and media experts as well as reviewers 1 teacher and 12 grade fourth elementary school students. Data collection methods and data analysis using questionnaire and descriptive analysis methods. In trials by material experts, the score percentage of $90 \%$, by learning design experts with a score percentage of 92,5\%, media experts obtained results with a score percentage of $95 \%$, so from the experts obtained category A very good qualification (very feasible). The results of the review from 1 grade IV elementary school teacher with a score percentage of $91.7 \%$, review of 3 students in individual trials with a score percentage of $91.1 \%$, the results of user reviews 12 students in the small group trial with a score percentage of $93.9 \%$, were in the category A very good qualification (very feasible). Based on the result that obtained, the interactive learning multimedia content material Indonesia's cultural diversity is very feasible and can be used in social sciences learning for fourth grade students of Elementary School.
\end{abstract}

\section{Introduction}

During the Covid-19 pandemic, learning was conducted online, making the most of e-learning and digital communication media. The implementation of the learning process from home or distance is carried out in accordance with the Circular letter of the Minister of Education and Culture No. 4 of 2020 on the 
implementation of education policy in the emergency period of the spread of Coronavirus Disease (Covid-19). In the circular explained that through online or distance learning is expected to still be able to provide meaningful experiences, as well as varied learning activities. The Covid-19 pandemic, which resulted in the implementation of online or distance learning, has an influence on the continuity of the learning process, especially in Indonesia, which is influenced by the limitations of mastery and availability of information technology in the form of IT or digital-based learning media ( Aji, 2020; Susanto, 2020). In the implementation of home or distance learning, teachers can no longer play the role of being the only informant or source of information for students. Teachers need media assistance that can be used as a source of self-learning and also a medium of effective and efficient distribution of learning information used when learning from home or distance. Learning media can overcome the limitations of the experience possessed by students, exceed classroom boundaries, produce uniformity or similarity of observation, motivate and spur students to learn (Rosita, 2015; Prabaningrum \& Putra, 2019). One of the learning content is Social Sciences, can not be separated from the curriculum that contains Social Sciences as a learning content for education at the elementary school level. In a research by Basori (2016) it was found that for elementary school students Social Sciences learning is considered difficult and less interesting, this has also been proven through observations and interviews conducted, where the results of interviews justify previous findings that elementary school students, especially grade IV elementary school consider Social Sciences as boring content.

Through pre-research observations on Social Sciences learning grade IV elementary students, it was found that the use of learning media in Social Sciences learning content is still too monotonous and less innovative. The problem that many schools experience at the elementary school level when carrying out online or distance learning is the availability of learning media software in learning Social Sciences content in the form of interactive multimedia is still insignificant. Indonesia cultural diversity material is one of the important materials Social Sciences learning in elementary schools. Cultural diversity in Indonesia from Sabang to Merauke must still be appreciated, maintained and preserved starting from the younger generation. The number of existing cultures (broad \& complex material), can affect students' ability to remember and understand the material (Ahmadi, 2017). The need of Social Sciences learning media in the implementation of distance or online learning, the decline of the exaltation of the younger generation to the nation's culture, the low knowledge of the younger generation about the diversity of Indonesian culture that causes a shift in cultural values due to the influence of globalization, must be addressed immediately. Countermeasures can be started from the elementary school level. With extensive material and need visualization of examples, it is very good that this material of cultural diversity is summarized in a media that can help students in remembering the variety of regional cultures and overcome the boredom of students to the existing Social Sciences learning content by developing an interactive and innovative learning media by utilizing technology and having a design that suits the characteristics and growth of grade IV elementary school students.

One of the most complete types of media is Multimedia, which can be seen as a learning tool and also a means of communication (Inceday, 2018; Suryanda, Ernawati, \& Maulana, 2016). Multimedia components are processed and integrated digitally using computer devices. Interactive Multimedia used in learning can have a positive impact in facilitating student learning process (Sanusi, 2015; Kariadnyani, Suartama, \& Sumantri, 2016). Phillip explain multimedia as a neatly arranged display of text, images, sounds, animations, and videos in a clear program that can involve the user's activities in controlling it (Putra, 2018). Multimedia learning in its use can stimulate students' interest and motivation in learning so that it has a good impact in handling the problem boredom of students in learning (Kuswanto, 2017). The more interesting the interactive learning multimedia display, the more motivating students can be in learning, thus improving student learning outcomes (Resiani, 2015). Interactive learning multimedia has the ability to present text, images, animation, and video at once, so as to serve the differences in characteristics of students, especially students at the elementary school level (Ramansyah, 2016). Newby said that the advantage of interactive multimedia as a learning media is that it can motivate and make students more interactive (Nopriyanti, 2015). The advantages of interactive learning multimedia are that students are empowered to control the learning environment, increase students' learning motivation, there is feedback, control is entirely in the user (Istiqlal, 2017). Multimedia used in the right direction can help psychomotor development and visual processing of its users ( Putra \& Ishartiwi, 2015). One of the programs or software on computer devices that is very good used to create interactive learning multimedia is Articulate Storyline that supports the creation of interesting animations with a simple interface (Yasin, 2017).Articulate Storyline is a software that is often used to orient information with specific purposes ((Pratama, 2018). Articulate Storyline app has the ability to combine slides, flash, video, characters, audio, and animations into one (Darnawati, 2019). The advantages of using Articulate Storyline software in the creation of interactive learning multimedia has been proven through research conducted by Thomas (2015). that successfully influences the involvement of students or learners in learning as well as ease of use and access. 
Interactive Learning Multimedia is the right choice to be a solution to the learning media problems needed in the implementation of online or distance learning and become the most suitable type of media to present materials of Indonesia's cultural diversity neatly, clearly, and pleasantly. This research is also supported and in line with previous research, namely research by Rofiq (2019) by developing Interactive Learning Multimedia obtaining research results that are interactive learning multimedia is very feasible to be used in Social Sciences learning and positively affect student learning outcomes. Research by Geni, et al (2020) who conducted development research by developing Interactive Learning Multimedia for elementary school thematic learning that obtained the results of multimedia products developed is very feasible to be used to help students in learning. Then in line with the research conducted by Abduramhman, et al (2020) who obtained the results of research that Interactive Learning Multimedia can improve students' learning outcomes in Social Sciences learning so that interactive learning multimedia is feasible and effectively used in the learning process. Furthermore, in line with the research on the development of Interactive Multimedia Learning for grade $\mathrm{V}$ elementary students conducted by Dwiqi, et al (2020) who obtained the results of research that interactive multimedia learning is effective in improving the learning outcomes of elementary school students and worthy to be used in the learning process.

Developed media has several advantages that are not owned and different from pre-existing media because it was developed based on Richard Mayer's cognitive theory, which is based on the theory that human or child working memory has two sub-components that work parallelly, namely Visual (vision) and Auditory (Hearing) Clark (2020) designed using Articulate Storyline3 which is the latest and best version today. Designed not to burden both Visual and Auditory sub-components, this product is also designed by utilizing Indonesian Culture Diversity Animation, Batik, and Wayang as Indonesia's world-recognized cultural heritage. Different from existing products that are mostly only accessible using android smartphones, this product can be used in various types of android and ios smartphones and also computers because it is an HTML5 application that can be accessed simply by sending a link of the HTML5 application to students. The research with the title "Development of Interactive Learning Multimedia Indonesia's Cultural Diversity Material in Social Sciences Learning for Grade IV Elementary School Students" was carried out aimed to develop learning media in the form of interactive learning multimedia with the content material Indonesia's cultural diversity in the learning of Social Sciences grade IV elementary school students to be a solution to the problems of learning media needed in the implementation of online or distance learning, planting and strengthening cultural values in the younger generation, as well as improving the knowledge of elementary school students to the diversity of Indonesian culture.

\section{Method}

This research is a type of development research or R\&D by using a development research model that is ADDIE model (Analysis, Design, Development, Implementation, and Evaluation). This development develops a learning media that produces a learning media in accordance with existing development theories (Haryono, 2015). This ADDIE model is based on theoretical foundation and systematically organized in learning problem solving efforts designed to the needs and characteristics of research subjects (Tegeh, 2013). ADDIE model consists of 5 stages of development, namely: (1) Analysis, (2) Design, (3) Development, (4) Implementation, (5) Evaluation. The following is an explanation of each stage of the ADDIE model: (1) Analysis stage, at this stage analysis of the situation, analysis of needs, identifying problems, identifying products that correspond to the subject of research, (2) Design, designing product concepts developed as expected and needed, (3) Development, at this stage carried out activities to realize product design that has been designed or validate products , (4) Implementation, product trials as a concrete step to implement ready-to-use products, (5) Evaluation, in this process it is seen whether the product made successfully or in accordance with the expected specifications or not. For product trial design in this research is carried out through several stages, namely: (a) The results of products that have been approved by the supervisor are validated by material experts, learning design experts, and media experts. Inputs and suggestions from materials experts, learning design experts, and media experts are used for product improvements or revisions. (b) Product revisions are revalidated by material experts, learning design experts, and media experts until they obtain good validation results and deserve to be tested to users or respondents, namely grade IV teachers and grade IV elementary school students. Data validation results and review from material experts, learning design experts, media experts, teachers, and students are processed to be able to obtain information related to the product so that it is known the level of quality and feasibility of interactive learning multimedia Indonesia's cutural diversity material in Social Sciences learning for grade IV Elementary School students.

The validators in this research are material expert, learning design experts, and media expert. Material experts are lecturers who have qualifications and have an understanding of Social Sciences learning materials. Learning design experts are teacher and lecture. Teacher and lecture who have qualifications in learning design, 
have an understanding of the curriculum and RPP and understand the learning in elementary school, namely grade IV teacher at SD Negeri 3 Sesetan South Denpasar Subdistrict and lecturer of the Faculty of Education Undiksha. Media expert is lecturer who have qualifications or graduate in the field of Education Technology. Then Users are 1 grade IV elementary school teacher and 3 grade IV students of SD Negeri 3 Sesetan with low, medium, and high learning abilities or achievements. The small group trial involved 12 grade IV students at SD Negeri 3 Sesetan. The subject of the research is learning media in the form of Interactive Learning Multimedia with Indonesia's cultural diversity material specifically designed to be used in Social Sciences learning and in accordance with the characteristics of grade IV elementary school students.

The data collection method used in this research is questionnaire. For validation questionnaire by learning media experts consists of 10 points of statement based on the questionnaire statement for research on the development of learning media by Suartama (2016) and 4 answer options, Strongly Agree (4), Agree (3), Disagree (2), and (1) Strongly Disagree, using the likert scale. For a questionnaire of media experts contains an assessment of interactive learning multimedia products made. The important points contained in the questionnaire statement are about aspects of interactive learning multimedia display in the form of background selection, suitability of font size and type, loaded images, animations used, audio in the form of backsound and narration, video, then programming and software aspects in the form of ease of operation or use of interactive learning multimedia products, navigation buttons provided, flexibility, and program interactivity. For validation questionnaires by material experts consists of 15 points of statement based on the questionnaire statement for research on the development of learning media by Suartama (2016) and 4 answer options, Strongly Agree (4), Agree (3), Disagree (2), and (1) Strongly Disagree using the likert scale. Questionnaire for content or material experts contains about aspects of content or material that is related to the suitability of the material with KD, accuracy of material, clarity of material, material similarity with characteristics and development of students, delivery of material, depth and completeness of presentation of materials in multimedia, as well as ease of understanding of material. For validation questionnaires by learning design experts consists of 15 statements based on questionnaire statements for research on the development of learning media by Suartama (2016) and 4 answer options, Strongly Agree (4), Agree (3), Disagree (2), and (1) Strongly Disagree, using the likert scale. Questionnaire for learning design experts (instructional) contains about aspects of learning in multimedia related to the design of learning activities such as can motivate, help remember previous knowledge, given practice questions or quizzes that can measure the ability of students (users), as well as consistency between goals, materials, and exercises / quizzes. For the questionnaire the response of teacher and students to the product contains about the aspects of the attractiveness of interactive learning multimedia products, aspects of ease of use and understanding of materials in interactive learning multimedia applications.

This research uses Descriptive Analysis Method, (1) Qualitative Descriptive Analysis is a way used to analyze or process data by arranging it into sentences or categories systematically related to the object studied so that a conclusion from the analysis is obtained (Agung, 2014). This qualitative descriptive analysis method is used to analyze and process data from review results by media expert, material or content expert, learning design experts (instructional), teacher and students in the form of responses, criticisms and suggestions or inputs given to interactive learning multimedia Indonesia cultural diversity material developed. (2) Quantitative Descriptive Analysis, is a way used to process data by arranging it into the form of percentages or numbers related to the object studied so as to obtain a conclusion (Agung, 2014). Quantitative descriptive analysis is used to process data obtained from questionnaires in the form of data in the form of numbers or scores. The results of quantitative data analysis are then analyzed using the media feasibility criteria that have been determined and then used to conclude or make a decision on the feasibility of learning media in the form of Interactive Learning Multimedia that has been developed. The following are grids questionnaire for material/content experts, instructional design experts, media experts, likert scale assessments, and media eligibility criteria or categories.

Table 1. Media Expert Questionnaire Grid

\begin{tabular}{|c|c|c|c|c|}
\hline No & Aspects & Indicators & $\begin{array}{l}\text { Instrument } \\
\text { Item No. }\end{array}$ & $\begin{array}{l}\text { Number of } \\
\text { Instruments }\end{array}$ \\
\hline \multirow[t]{6}{*}{1} & Multimedia & Accuracy of background selection with material & 1 & 1 \\
\hline & Display & Accuracy of font size and type selection & 2 & 1 \\
\hline & & $\begin{array}{l}\text { Visual image display quality (design, typography, } \\
\text { color) }\end{array}$ & 3 & 1 \\
\hline & & $\begin{array}{l}\text { The attractiveness and suitability of animation with } \\
\text { the material }\end{array}$ & 4 & 1 \\
\hline & & Audio clarity and attractiveness (narration, music) & 5 & 1 \\
\hline & & Suitability of video selection with materials & 6 & 1 \\
\hline
\end{tabular}




\begin{tabular}{|c|c|c|c|c|}
\hline No & Aspects & Indicators & $\begin{array}{l}\text { Instrument } \\
\text { Item No. }\end{array}$ & $\begin{array}{l}\text { Number of } \\
\text { Instruments }\end{array}$ \\
\hline \multirow[t]{5}{*}{2} & \multirow{4}{*}{$\begin{array}{l}\text { Programming } \\
\text { and Software }\end{array}$} & Smoothness and ease of operation & 7 & 1 \\
\hline & & Accuracy of using navigation keys & 8 & 1 \\
\hline & & Flexibility (can be used independently and guided) & 9 & 1 \\
\hline & & $\begin{array}{l}\text { Accuracy of interactive link performance } \\
\text { (Interactivity) }\end{array}$ & 10 & 1 \\
\hline & & Total & & 10 \\
\hline
\end{tabular}

Table 2. Content/Materials Expert Questionnaire Grid

\begin{tabular}{cllcc}
\hline No & \multirow{2}{*}{ Aspects } & \multicolumn{1}{c}{ Indicators } & $\begin{array}{c}\text { Instrument } \\
\text { Item No. }\end{array}$ & $\begin{array}{c}\text { Number of } \\
\text { Instruments }\end{array}$ \\
\hline 1 & $\begin{array}{l}\text { Content and } \\
\text { Materials in } \\
\text { Multimedia }\end{array}$ & $\begin{array}{l}\text { Conformity of material to the scope of Social } \\
\text { Sciences } \\
\text { Material comformity with KD }\end{array}$ & 1 & 1 \\
& Accuracy of the material presented & 2 & 1 \\
& Depth of material presented & 3 & 1 \\
& Conformity of the material to the student's condition & 4 & 1 \\
& Material conformity with student characteristics & 6 & 1 \\
& Material conformity with student development & 7 & 1 \\
& Presentation of materials provides an opportunity for & 8 & 1 \\
& self-learning & 9 & 1 \\
& Delivery of interesting material & 10 & 1 \\
& Easy-to-understand material & 11 & 1 \\
& Provide other resources for learning & 12 & 1 \\
& Pay attention to individual differences & 13 & 1 \\
& Suitability and completeness of example presentation & 14 & 1 \\
& Language compatibility with the user's goals & 15 & \\
& Suitability of exercise/quiz questions & & 15 \\
\hline
\end{tabular}

(Suartama, 2016, with researcher modifications)

Table 3. Instructional Design Expert Questionnaire Grid

\begin{tabular}{|c|c|c|c|c|}
\hline No & Aspects & Indicators & $\begin{array}{l}\text { Instrument } \\
\text { Item No. }\end{array}$ & $\begin{array}{l}\text { Number of } \\
\text { Instruments }\end{array}$ \\
\hline \multirow[t]{16}{*}{1} & Learning & Clarity of learning objectives & 1 & 1 \\
\hline & Activity & Consistency between objectives, materials, and quizzes & 2 & 1 \\
\hline & \multirow[t]{14}{*}{ Design } & Delivery of logical materials & 3 & 1 \\
\hline & & Clear material delivery & 4 & 1 \\
\hline & & Clear learning instructions & 5 & 1 \\
\hline & & Learning can motivate students & 6 & 1 \\
\hline & & Assist students in remembering materials & 7 & 1 \\
\hline & & Provide examples & 8 & 1 \\
\hline & & Giving a puller attention & 9 & 1 \\
\hline & & Provide students with opportunities to learn independently & 10 & 1 \\
\hline & & Learning has a free and clear navigation flow & 11 & 1 \\
\hline & & Given appropriate question/quiz practice & 12 & 1 \\
\hline & & $\begin{array}{l}\text { Practice questions/quizzes can measure students' ability } \\
\text { and memory }\end{array}$ & 13 & 1 \\
\hline & & $\begin{array}{l}\text { Practice questions/quizzes can be used repeatedly to } \\
\text { practice memory }\end{array}$ & 14 & 1 \\
\hline & & Giving feedback on the results of a question/quiz exercise & 15 & 1 \\
\hline & & \multicolumn{2}{|l|}{ Total } & 15 \\
\hline
\end{tabular}

(Suartama, 2016, with researcher modifications) 
There are criteria or categories of Likert Scale assessment to describe the quality or feasibility of products made in this research. The results of questionnaires from media experts, material experts, learning design experts, teacher and students assembled interactive learning multimedia development Indonesia cultural diversity materials in social sciences learning for grade IV Elementary School students, obtained by comparing the number of respondents scores $\left(\sum \mathrm{R}\right)$ with the ideal number of scores $(\mathrm{N})$.

Table 5. Percentage and Eligibility Criteria of Material Expert data, Learning Design, Media, Teacher and Students

\begin{tabular}{lccl}
\hline No & Percentage (\%) & Qualifications & \multicolumn{1}{c}{ Description } \\
\hline 1 & $90-100 \%$ & Very Good & Very Feasible/Very Valid/No revision required \\
2 & $80-89 \%$ & Good & Feasible/Valid/No Revision Required \\
3 & $65-79 \%$ & Good Enough & Feasible Enough/Valid Enough/Revision required \\
4 & $55-64 \%$ & Less Good & Less Feasible/Less Valid/Revision required \\
5 & $0-54 \%$ & Very Not Good & Very Inappropriate/Very Invalid/Revision required \\
\hline
\end{tabular}

\section{Result and Discussion}

\section{Research Result}

The first stage is analysis, through observations and interviews conducted on respondents, found that Social Sciences learning media used in the form of image media and books, and has never used learning media that utilizes IT such as interactive learning multimedia in the form of software or applications. In observations at SD Negeri 3 Sesetan it was found that the school has adequate facilities and infrastructure to use media that utilizes IT such as projectors and projection screens and almost $99 \%$ of students already own and use mobile phones in carrying out distance or from home learning. Through interviews conducted with some grade IV elementary school students, it was found that they dislike Social Sciences learning as a result of many and extensive materials and have to remember and memorize such many materials, but the learning media used is too monotonous so make them bored and not interested in social sciences learning even less Indonesian culture diversity material that takes a long time to memorize it. The students interviewed also expect learning media by using IT that is easy to use, with an attractive design, fun, can be used anywhere and anytime, can also make them interested and excited and motivated to learn the material well and make it easier for them to remember and understand the material in the online or distance learning process.

The design stage is obtained and generated data related to the loaded material, multimedia flowcharts, and multimedia storyboards. The data obtained is data related to material contained in multimedia. Indonesia cultural diversity material which is the content materials in Social Sciences learning of grade IV elementary students, the data is obtained from teacher books and student books used in grade IV Elementary School. Data for materials taken from KD (Basic Competencies) contained in the teacher's book so that materials in accordance with the KD (Basic Competency) are collected. Then collect data in the form of names of traditional houses, traditional clothing, traditional dance, as well as regional songs from various provinces in Indonesia. In addition to collecting data in the form of cultural diversity materials in Indonesia, at this stage also collected data in the form of animated vector images, cartoon animation images selected according to the development, age and characteristics of elementary school students especially grade IV students. Data in the form of cartoon animated vector images collected through the website of the provider of free animated vector images, namely freepik.com. The vector data collected are in the form of animated images of children's cartoons, animated cartoons of Indonesian culture such as batik backgrounds, wayang images, traditional house cartoon animations, traditional clothing, traditional dance, and cartoon animation videos of Indonesia's regional songs. At this stage, Flowchart of interactive learning multimedia is produced, which is designed in the form of an application flowchart consisting of several menus, such as the sign in menu, core (instruction menu, KD, materials, videos, and quizzes) and exit menu. After the flowchart is created, the next step is to create a storyboard or sketch a multimedia design image called a storyboard. Storyboard is a sketch of an image made in the form of a sequence that is arranged according to the planned storyline, each storyboard is designed as interesting as possible and given clear instructions to be easy for the user to understand and use without overloading the senses used by users or students.

The next stage is the development stage, resulting in display design (Interface), Build and Publish interactive learning multimedia applications, questionnaire creation, and product validation by material experts, learning design experts, and media experts (Expert Test). The interface design or multimedia display of interactive learning is created using articulate storyline 3 application. Articulate Storyline does not require a 
programming language animation commands can be done with the feature on the trigger menu. Vector images and animations related to material downloaded from freepik.com (Provider of free vector images). The design is contained Indonesia Cultural Diversity, so the design is made nuanced Indonesian Culture that uses cartoon animation images that use typical clothing of Indonesia, batik background and wayang images as a cultural heritage of Indonesia. Designed not to burden the senses of the eye (Visual) by replacing the explanatory text with dubbing narrative explanations. The multimedia interface that have been designed are as follows.
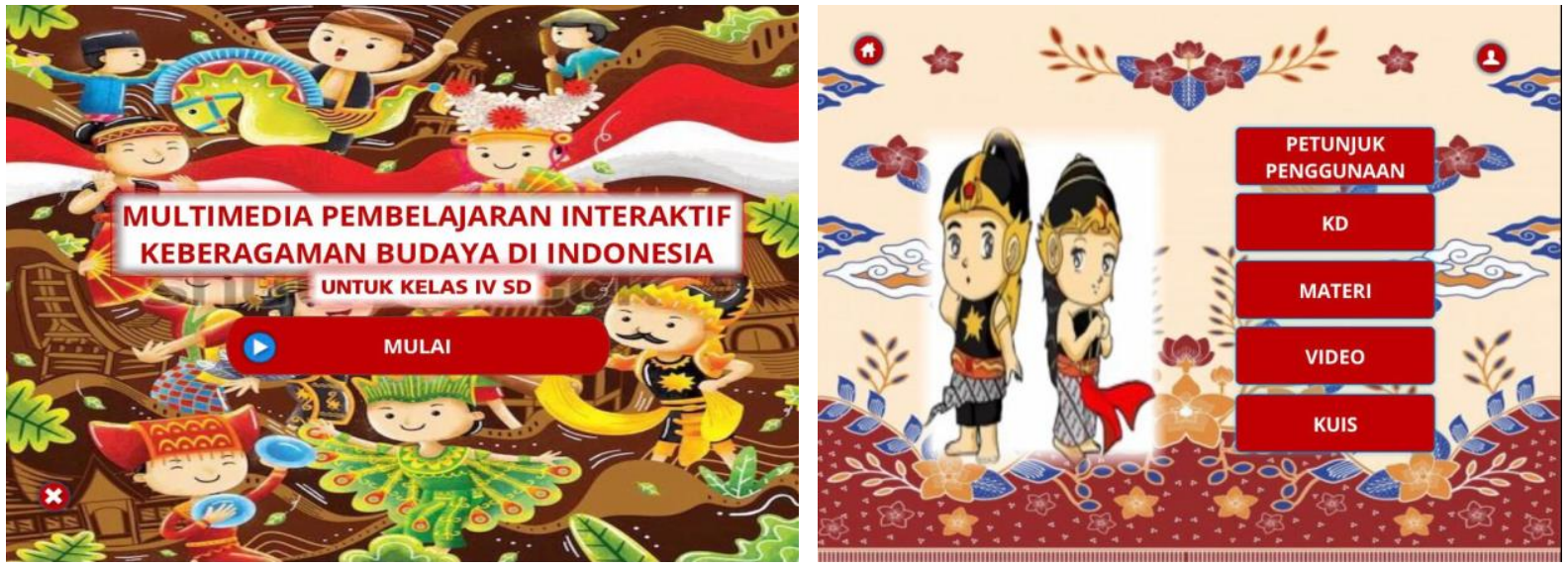

Pictures 2. Interactive Learning Multimedia Menu and Display Interface Design

Furthermore, multimedia learning displays or interface design either from the initial view, menus, buttons, animation assets, audio, video and material design of cultural diversity in Indonesia that has been created later on articulate storyline 3 application is given trigger animation settings and controls to run the application so that users can interact with multimedia learning, users can click the button or menu that the user wants such as the start button, material buttons, quis buttons, or KD as a form of interactiveness. And lastly is publishing interactive learning multimedia files created in Articulate Storyline 3 into application or program that can be sent and used on Gadgets, Smartphones or used on Laptops and Computers that are published in the form of HTML5.

Questionnaire creation for experts, teacher, and students. Instruments in the form of questionnaires are prepared to know the feasibility of the product in the form of interactive learning multimedia that has been developed. Validation questionnaire for material experts contains about aspects of content material that is related to the suitability of the material with $\mathrm{KD}$, accuracy of material, clarity of material, material conformity with characteristics and development of students, delivery of materials, depth and completeness of presentation materials in multimedia, as well as ease of understanding of material. Validation questionnaire for learning design experts containing aspects of learning in multimedia related to the design of learning activities such as can motivate, help remember previous knowledge, given practice questions or quizzes that can measure the ability of students (users), as well as consistency between goals, materials, and exercises or quizzes. Validation questionnaire for learning media experts contains aspects of interactive learning multimedia display (background selection, font type, image, animation, audio, and video), programming and software aspects (ease of operation or use of interactive learning multimedia products, navigation buttons, flexibility, and interactivity). Questionnaires for teacher and students' responses to products made contain about aspects of interactive learning multimedia products, aspects of ease use and understanding of materials in interactive learning multimedia applications.

Furthermore, product validation is carried out by experts as well as reviews from teachers and students. The validators in this study are media experts, materials experts, and learning design experts. Media expert, materials expert, and learning design experts are academically criterion experts. Reviewers are 1 grade IV elementary school teacher and 12 grade IV elementary school students. Validation results are obtained from the percentage of the questionnaire score, which is as follows.

Table 6. Questionnaire Results from Material/Content Experts

\begin{tabular}{lllll}
\hline No & QuestionnaireScore & Score Percentage & Category & Description \\
\hline 1 & 54 (from 60) & $90,0 \%$ & Very Good & Very Feasible \\
\hline
\end{tabular}


Material experts test with validator, lecturer of Faculty of Education, Ganesha University of Education by testing and validating the material / content of the media through RPP or The Implementation Plan of Learning and Syllabus. From the material experts obtained a score percentage of $90.0 \%$ including very good category and very feasible. Experts learning design test with validators, namely a senior teacher at SD Negeri 3 Sesetan South Denpasar Subdistrict, and lecturer of the Faculty of Education, Ganesha University of Education with a score percentage of $92.5 \%$ including a very good category and very feasible. Media expert test by validator lecturer of Education Technology Ganesha University of Education, validation results or assessment of the media that has been made obtained a percentage score of $95 \%$ including a very good category and very feasible.

Review or response from grade IV teachers at SD Negeri 3 Sesetan to interactive learning multimedia products developed that obtained the results of a questionnaire score of 55 from an ideal score of 60 , obtain a percentage score of $91.7 \%$ including a very good category and very feasible.

Table 7. Questionnaire Results from Individual Trials

\begin{tabular}{llllll}
\hline No & \multicolumn{1}{c}{ Respondents/users } & QuestionnaireScore & $\begin{array}{c}\text { Score } \\
\text { Percentage }\end{array}$ & Category & Description \\
\hline 1 & $\begin{array}{l}\text { Low learning achievement } \\
\text { student }\end{array}$ & 55 (from 60) & $91,7 \%$ & Very Good & Very Feasible \\
2 & $\begin{array}{l}\text { Medium learning } \\
\text { achievement student }\end{array}$ & 55 (from 60) & $91,7 \%$ & Very Good & Very Feasible \\
$\begin{array}{l}\text { High learning achievement } \\
\text { students }\end{array}$ & 54 (from 60) & $90,0 \%$ & Very Good & Very Feasible \\
\hline Total & $\mathbf{1 6 4}$ (from 180) & $\mathbf{9 1 , 1 \%}$ & Very Good & Very Feasible \\
\hline
\end{tabular}

The total score of the questionnaire in the individual trials is 164 out of an ideal score of 180 so that the percentage score in the individual test of $91.1 \%$ including very good category and very feasible.

Table 8. Questionnaire Results from Small Group Trials

\begin{tabular}{llcccc}
\hline No & \multicolumn{1}{c}{ Respondents/users } & $\begin{array}{c}\text { Questionnaire } \\
\text { Score }\end{array}$ & $\begin{array}{c}\text { Score } \\
\text { Percentage }\end{array}$ & Category & Description \\
\hline 1 & Group 1 (low learning achievement) & 56 from 60 & $93,3 \%$ & Very Good & Very Feasible \\
2 & $\begin{array}{l}\text { Group 2 (medium learning } \\
\text { achievement) }\end{array}$ & 57 from 60 & $95,0 \%$ & Very Good & Very Feasible \\
3 & Group3 (high learning achievement) & 56 from 60 & $93,3 \%$ & Very Good & Very Feasible \\
\hline Total & $\mathbf{1 6 9}$ (from 180) & $\mathbf{9 3 , 9 \%}$ & Very Good & Very Feasible \\
\hline
\end{tabular}

Small group trials, total questionnaire score of 169 from the ideal score of 180 so the score percentage in small group trials of $93.9 \%$ belongs to the very good category and very feasible. Implementation stage, the implementation stage was conducted field trials involving 1 grade IV elementary school consisting of 30 students to use the product and provide pretest and postest to know the effectiveness of the product but because it is still in a pandemic Covid-19 situation field trials can not be carried out because it can not be implemented face-to-face learning process or offline learning process.

Evaluation Stage, from the evaluation stage found several things to improve the product that has been developed. Data obtained from the analysis stage, design stage, development stage, several things related to the design of learning assembled with the design of learning by material experts are advised to add material in the form of facts related to the diversity of Indonesian culture and problems that occur as a result of existing cultural diversity. After obtaining advice and input from experts created a product that is categorized or has excellent qualifications according to experts who have been declared very feasible to be used in the Social Sciences learning, especially in the learning of grade IV elementary school students.

\section{Discussion}

In this development research the resulting product is Interactive Learning Multimedia developed specifically for grade IV elementary school students with material content Indonesia cultural diversity in Social Sciences learning. This interactive learning multimedia product was developed to facilitate grade IV elementary school students to be able to study the material of Indonesian cultural diversity independently and guided, overcome the boredom of students to monotonous Social Sciences learning media so that students are more 
excited in learning (Kariadnyani, Suartama, \& Sumantri, 2016; Manurung \& Panggabean, 2020). From the results of the research obtained using the ADDIE model through the analysis, design, development, implementation and evaluation phases, it is known that the media in the form of Interactive Learning Multimedia with the content of Indonesian Cultural Diversity materials in Social Sciences learning of Grade IV elementary school students developed is a very feasible media, this is in line with research by Geni, et al (2020) who also floated the media using the ADDIE model and obtained very good results. The results are obtained because the media in the form of multimedia learning is developed or designed using the latest and best multimedia maker software today, articulate storyline 3 with the ease of use of this software articulate storyline does not require programming language or script, animation commands can be done with features on the trigger menu so as to facilitate the creation of interactive learning multimedia this is in line with the findings of device development research in learning by Yahya, et al (2020). Articulate Storyline also has the ability to combine slides, flash, video, characters, audio, and animation into one so make multimedia developed very interesting by using all types of media, this is in line with the findings of research by Darnawati (2019) facilitated by these advantages in Articulate Storyline.

The interface design is made very attractive and adapted to the characteristics of grade IV elementary school students, obtain an excellent response from validators as well as respondents or reviewers. Based on the test results of the validity or feasibility of the product of the data collection instrument and the results of data analysis can be seen that the validator and also the respondent or reviewer gave a response or answer very agree to the statement that the design of interactive learning multimedia interface developed is very good and very interesting. In addition to the interface design statement that interactive learning multimedia background developed is very interesting and in accordance with the material contained also obtained a response or review that $99 \%$ of respondents gave a very agreeable answer that indicates that it is true the statement submitted that the selection of multimedia Background is very appropriate. Furthermore, in the aspect of the display, namely the size and type of font or text, visual image display, layout, typography, and colors used in multimedia, and animation also get a response or review that is the average answer respondents are very agreeable supported by validation from experts who also give answers strongly agree on statements related to the multimedia display of interactive learning developed. Then for Audio in the form of narration and backsound the average respondent chooses to strongly agree with the statement that Audio in the form of narration and Backsound / music is clear and interesting that can increase the spirit when listening to it. Furthermore, the selection of videos with the average answer of respondents and experts is very agreed with the statement that the video contained in multimedia is interesting and entertaining so as to overcome the boredom of students in learning, this is in line with the results of research by Oktaflani (2020) who obtained similar respondent results that obtained an average of very agreeable answers that showed that these aspects are very good and very feasible.

The quality and feasibility of Multimedia Interactive Learning developed is also influenced by the advantages that are owned in the form of HTML5 applications so that it can be accessed easily by various types of android smartphones and ios and also computers that are not owned by the previous product that can only be accessed on a computer because it is a $\mathrm{CD}$ or can only be accessed through android smarthphone which is the product produced in the research by Roriq, et al (2019), Shebastian (2020) and also research by Geni, et al (2020). Through the first expert test conducted, namely the expert test material / content to validate the material or content in the multimedia product interactive learning content of cultural diversity material in Indonesia. Validators in the test of materials or content experts, namely lecturers of Ganesha Education University who have qualifications in Social Sciences learning obtained a percentage score of $90.0 \%$ including a very good category so material or content media is very feasible, this result is in line with the findings or results of research by Ragil Saputra, et al (Saputra, 2017) who obtained a percentage score of 91.6\% which was declared very good or very feasible. The learning design expert test was validated by 2 validators who have qualifications in learning design in elementary school, namely 1 grade IV elementary school teacher who has experienced for a dozen years (senior teacher) by obtaining a percentage score of $92.5 \%$ including a very good category with instructional design information (learning) is very feasible, this result is in line with the findings of research by Pratiwi (2028) by obtaining a percentage score of $90 \%$ excellent qualifications. The use of interactive learning multimedia is stated to be able to improve the mastery of concepts, learning achievements as well as the ability to think critically and self-learning students, especially in distance learning / online at the elementary school level, this is in line with research conducted (Kurniawati, 2018). Test by media experts, the product is validated by the validator, obtained a percentage score of $95.0 \%$ included in the category of very good with very decent media information, in line with the results of research found by Nugraha (2019) which obtained a percentage score of $92.9 \%$ very good category. The results of teacher riview, individual and small group trials with a score percentage of $91.7 \%, 91.1 \%$ and $93.9 \%$ of category A qualifications are very good with very decent product descriptions, in line with the results of research by (Rofiq, 2019) with the acquisition of $92.6 \%$ and $93.3 \%$ of the categories very good, thus showing a good response from product users, that is grade IV elementary school students. 
Through the results of validation and trials conducted on Interactive Learning Multimedia developed in this study, by obtaining a percentage of the overall score from experts, riviwers namely teachers and grade IV elementary students, fall into category A with excellent qualifications or quality and the product is declared very viable. From the results and various findings that have been presented in the discussion, it has shown the quality and feasibility of this Interactive Learning Multimedia product as a very good and very feasible media.

\section{Conclusion}

The results of data analysis obtained using data collection instruments in the form of questionnaires from materials / content experts, instructional design experts, reviewers, namely teachers, as well as grade IV elementary students by obtaining category A qualifications are very good with the quality of media or products is very feasible. Therefore, from the results and various findings in this research, it can be concluded that Interactive Learning Multimedia Indonesia's Cultural Diversity Material developed based on multimedia cognitive theory Richard Mayer is very feasible to be used in the learning of Social Sciences learning grade IV elementary school students because it is a learning media by utilizing that is very interesting with the advantages of media can be accessed easily through HTML5 applications with digital media gadgets, computers, and smartphones so that it is very suitable with the needs of learning media in the implementation of online learning.

\section{References}

Agung, A. A. G. (2014). Buku Ajar Metodologi Penelitian Pendidikan. Yogyakarta: Aditya Media Publishing.

Abdurrahman, et al. (2020). "Pengembangan Multimedia Pembelajaran Interaktif untuk Meningkatkan Hasil Belajar IPS". Jurnal EDUTECH Universitas Pendidikan Ganesha, 8(1), 32-45. http://dx.doi.org/10.23887/jeu.v8i1.27049

Ahmadi, , et al. (2017). "Pengembangan Media Edukasi "Multimedia Indonesian Culture". Jurnal Penelitian Pendidikan, 34(2), 127-136. https://doi.org/10.15294/jpp.v34i2.12368.

Amaruddin, H., Atmaja, H. T., \& Khafid, M. (2020). Peran Keluarga Dan Media Sosial Dalam Pembentukan Karakter Santun Siswa Di Sekolah Dasar. Jurnal Pendidikan Karakter, 10(1). https://doi.org/https://doi.org/10.21831/jpk.v10i1.30588.

Aji, Rizqon Halal Syah. (2020). "Dampak Covid-19 pada Pendidikan di Indonesia: Sekolah, Keterampilan, dan Proses Pembelajaran”. Jurnal SALAM: Jurnal Sosial \& Budaya Syar-i, 7(5), 395-402. http://dx.doi.org/10.15408/sjsbs.v7i5.15314.

Asriani, P., Sa'dijah, C., \& Akbar, S. (2017). Bahan Ajar Berbasis Pendidikan Karakter Untuk. Jurnal Pendidikan: Teori, Penelitian, Dan Pengembangan, 2(11), 1456-1468. https://doi.org/http://dx.doi.org/10.17977/jptpp.v2i11.10160

Basori, Muhamad. (2016). "Pengembangan Multimedia Interaktif untuk Mata Pembelajaran Ilmu Pengetahuan Sosial (IPS) Sekolah Dasar Kelas V”. Jurnal Pendidikan Dasar Nusantara, 1(2), 75-80. https://doi.org/10.21831/jpe.v1i1.2311

Clark, R. Colvin, and Richard E. Mayer. (2016). E-Learning and the Science of Instruction: Proven Guidelines for Consumers and Designers of Multimedia Learning, (Fourth ed). https://www.learnlab.org/research.

Darnawati, , et al. (2019). "Pemberdayaan Guru Melalui Pengembangan Multimedia Pembelajaran Interaktif Dengan Aplikasi Articulate Storyline". Jurnal Pengabdian Kepada Masyarakat, 1(1), 8-16. http://dx.doi.org/10.36709/amalilmiah.v1i1.8780

Dwiqi, G C. Smaramanik, et al. (2020). "Pengembangan Multimedia Pembelajaran Interaktif Mata Pelajaran IPA Untuk Siswa SD Kelas V”. Jurnal EDUTECH Universitas Pendidikan Ganesha, 8(2), 33-48. http://dx.doi.org/10.23887/jeu.v8i2.28934

Geni, K H Y. Wijaya, , et al. (2020). "Pengembangan Multimedia Pembelajaran Interaktif Berpendekatan CTL Pada Pembelajaran Tematik Siswa Kelas IV SD”. Jurnal EDUTECH Universitas Pendidikan Ganesha, 8(2), 1-16. http://dx.doi.org/10.23887/jeu.v8i2.28919.

Haryono, Nugraheni Dinasari. (2015). "Pengembangan Multimedia Interaktif Sebagai Media Pembelajaran IPS Bagi Siswa Kelas IV SD Negeri Tegalpanggung”. Jurnal Pendidikan Guru Sekolah Dasar, 4(17), 1-8. https://eprints.uny.ac.id. 
Incedayi, Necdet. (2018). "The Impact of Using Multimedia Technologies on Student Academic Achievement in the Barkirkoy Final College”. Interantional Journal of Humanities Social Sciences and Education, 5(1), 40-47 http://dx.doi.org/10.20431/2349-0381.0501007www. arcjournals.org.

Istiqlal, Muhammad. (2017). "Pengembangan Multimedia Interaktif dalam Pembelajaran Matematika". Jurnal $\begin{array}{llll}\text { Ilmiah Pendidikan } & \text { Matematika, }\end{array}$ http://journal.upgris.ac.id/index.php/JIPMat/article/view/1480.

Kariadnyani, Suartama, \& Sumantri. (2016). Pengaruh Model Course Review Horay Berbantuan Multimedia Terhadap Hasil Belajar IPA Siswa Kelas V SD. Mimbar PGSD Undiksha, 4(1). https://doi.org/http://dx.doi.org/10.23887/jjpgsd.v4i1.7467

Kurniawati, I. D., dan Sekreningsih Nita. (2018). "Media Pembelajaran Berbasis Multimedia Interaktif untuk Meningkatkan Pemahaman Konsep Mahasiswa". Journal of Computer and Information Technology, 1(2), 68-75. http://doi.org/10.25273/doubleclick.v1i2.1540

Kuswanto, Joko, dan Yosita Walusfa. (2017). "Pengembangan Multimedia Pembelajaran pada Mata Pelajaran Teknologi Informasi dan Komunikasi Kelas VIII”. Inovative Journal of Curiculum and Educational Technology, 6(2), 58-64. https://doi.org/10.15294/ijcet.v6i2.19335

Manurung, \& Panggabean. (2020). Improving Students' Thinking Ability In Physics Using Interactive Multimedia Based Problem Solving. Cakrawala Pendidikan, 39(2), 460-470. https://doi.org/https://doi.org/10.21831/cp.v39i2.28205

Nopriyanti. (2015). "Pengembangan Multimedia Pembelajaran Interaktif Kompetensi Dasar Pemasangan Sistem Penerangan dan Wiring Kelistrikan di SMK". Jurnal Pedidikan Vokasi, 5(2), 222-235. https://doi.org/10.21831/jpv.v5i2.6416

Nugraha, G N. Satria, et al. (2019). "Pengembangan Multimedia Interaktif Matematika Berorientasi Kearifan Lokal Kelas 3 Sekolah Dasar Negeri 1 Paket Agung”. Jurnal EDUTECH Universitas Pendidikan Ganesha, 7(1), 12-22. http://dx.doi.org/10.23887/jeu.v7i1.19972

Oktaflani, Dian, dkk. (2020). "Pengembangan Multimedia Interaktif Matematika Berorientasi Kearifan Lokal Kelas 3 Sekolah Dasar Negeri 1 Paket Agung”. Jurnal Mimbar PGSD Undiksha, 8(3), 527-540.

Pratama, Ryan Angga. (2018). "Media Pembelajaran Berbasis Articulate Storyline 2 pada Materi Menggambar Grafik Fungsi di SMP Patra Dharma 2 Balikpapan”. Jurnal Dimensi Unrika, 7(1), 19-35. https://www.journal.unrika.ac.id/index.php/jurnaldms/article/view/1631/1187.

Pratiwi, N P E. Yunita, et al. (2018). "Pengembangan Multimedia Pembelajaran Interaktif Berbasis Proyek pada Mata Pelajaran Bahasa Indonesia pada Siswa Kelas V". Jurnal EDUTECH Universitas Pendidikan Ganesha, 6(1), 123-133. http://dx.doi.org/10.23887/jeu.v6i1.20277.

Putra, L. D., Ishartiwi. (2015). "Pengembangan Multimedia Pembelajaran Interaktif Mengenal Angka dan Huruf untuk Anak Usia Dini”. Jurnal Inovasi Teknologi Pendidikan, 2(2), 169-178. https://doi.org/10.21831/tp.v2i2.7607

Putra, Lovandri Dwanda. (2018). "Pengembangan Multimedia Pembelajaran Interaktif Pengenalan Pariwisata Lokal Berbasis Macromedia Flash untuk siswa Sekolah Dasar Yogyakarta”. Jurnal JPSD, 5(2), 46-51. http://dx.doi.org/10.12928/jpsd.v5i2.12583

Rafmana, Hesta, , et al. (2018). "Pengembangan Multimedia Interaktif Berbasis Articulate Storyline untuk Meningkatkan Motivasi Belajar Siswa Pada Mata Pelajaran PKn Kelas XI di SMA Srijaya Negara Palembang”. Jurnal Bhinneka Tunggal Ika, 5(1), 52-65. https://doi.org/10.36706/jbti.v5i1.7898

Ramansyah, Wanda. (2016). "Pengembangan Multimedia Pembelajaran Interaktif Dengan Tema Pengenalan Huruf Hijaiyah Untuk Peseta didik Sekolah Dasar". Jurnal Imiah EDUTIC, 3(1), 28-37. https://doi.org/10.21107/edutic.v3i1.2558

Resiani, N K, et al. (2015). "Pengembangan Multimedia Pembelajaran Interaktif Pada Mata Pelajaran IPS Siswa Kelas VII Semester Genap di SMP N 7 Singaraja Tahun Ajaran 2014/2015”. Jurnal EDUTECH, 3(1) http://dx.doi.org/10.23887/jeu.v3i1.5929

Rofiq, Abdul, et al. (2019). "Pengembangan Multimedia Pembelajaran Interaktif pada Mata Pelajaran IPS Terpadu". Jurnal of Education Technology Universitas Pendidikan Ganesha, 3(3), 126-133. http://dx.doi.org/10.23887/jet.v3i3.21732 
Rosita, Farida Yufarlina. (2015). "Pengembangan Multimedia Interaktif Untuk Pembelajaran Berbicara Bagi Siswa Kelas IV Sekolah Dasar". Jurnal Inovasi Pembelajaran, 1(1), 25-37. https://doi.org/10.22219/jinop.v1i1.2445

Saputra, I K. Ragil, et al. (2017). "Pengembangan Multimedia Pembelajaran Interaktif Berbasis Game Berorientasi Pendidikan Karakter Pada Mata Pelajaran Bahasa Inggris Kelas IV di SD Mutiara Singaraja Tahun Pelajaran 2017/2018”. Jurnal EDUTECH Universitas Pendidikan Ganesha, 5(2), http://dx.doi.org/10.23887/jeu.v5i2.20369

Shebastian, Ryan, et al. (2020). "Pengambangan Media Pembelajaran Interaktif "Pengenalan Hewan dan Tumbuhan" pada Mata Pelajaran Ilmu Pengetahuan Alam (IPA) dengan Metode Gamefikasi untuk Siswa Kelas II di Sekolah Dasar (Studi Kasus: SDN 2 Batur)". Junal KARMAPATI, 9(1), 8-20. http://dx.doi.org/10.23887/karmapati.v9i1.23270

Sanusi, et al. (2015). "Pengembangan Multimedia Interaktif Sebagai Media Pembelajaran Pada Pokok Bahasan Dimensi Tiga di Sekolah Menengah Atas". Jurnal Imiah Pendidikan Matematika, 3(2), 398- 416. http://doi.org/10.25273/jipm.v3i2.510

Suartama, I Kadek. (2016). Evaluasi dan Kriteria Kualitas Multimedia Pembelajaran. Singaraja: Universitas Pendidikan Ganesha.

Sugiyono. (2019). Metode Penelitian Pendidikan. Bandung: Alfabeta.

Susanto, Ahmad. (2014). Pengembangan Pembelajaran IPS di Sekolah Dasar. Jakarta: Kencana.

Susanto, Eri dan A P. Deapalupa. (2020). "Analisis Dampak Covid-19 Terhadap Implementasi Study From Home (SFH) di Tingkat Sekolah Dasar”. Jurnal Pendidikan: Riset \& Konseptual, 4(4), 536-542. http://journal.unublitar.ac.id/pendidikan/index.php/Riset_Konseptual.

Tegeh, I Made dan I M. Kirna. (2013). "Pengembangan Bahan Ajar Metode Penelitian Pendidikan Dengan ADDIE Model”. Jurnal IKA Universitas Pendidikan Ganesha, 11(1), 12-26. http://dx.doi.org/10.23887/ika.v11i1.1145

Thomas, Jenny, et al. (2015). "Integrated Anatomy E-Tutorial Designed by Medical Students, Combining Articulate Storyline 2 With Images from Anatomy TV'. Proceeding of EDULEARN15 Conference University of Glasgow, pp 1922-1929. https://www.researchgate.net/publication/280038738.

Yahya, Rizky, et al. (2020). "Pengembangan Perangkat Pembelajaran Flipped Classrom Bercirikan MiniProject". SJME (Supremun Journal of Mathematics Education), 4(1), 78-91. https://doi.org/10.35706/sjme.v4i1.3136

Yasin, Apin Nasifah et al. (2017). "Kelayakan Teoritis Multimedia Interaktif Articulate Storyline Materi sistem Sistem Reproduksi”. Jurnal UNESA Bioedu Berkala Ilmiah Pendidikan Biologi, 6(2), 169-174. https://jurnalmahasiswa.unesa.ac.id/index.php/bioedu/article/view/20868. 